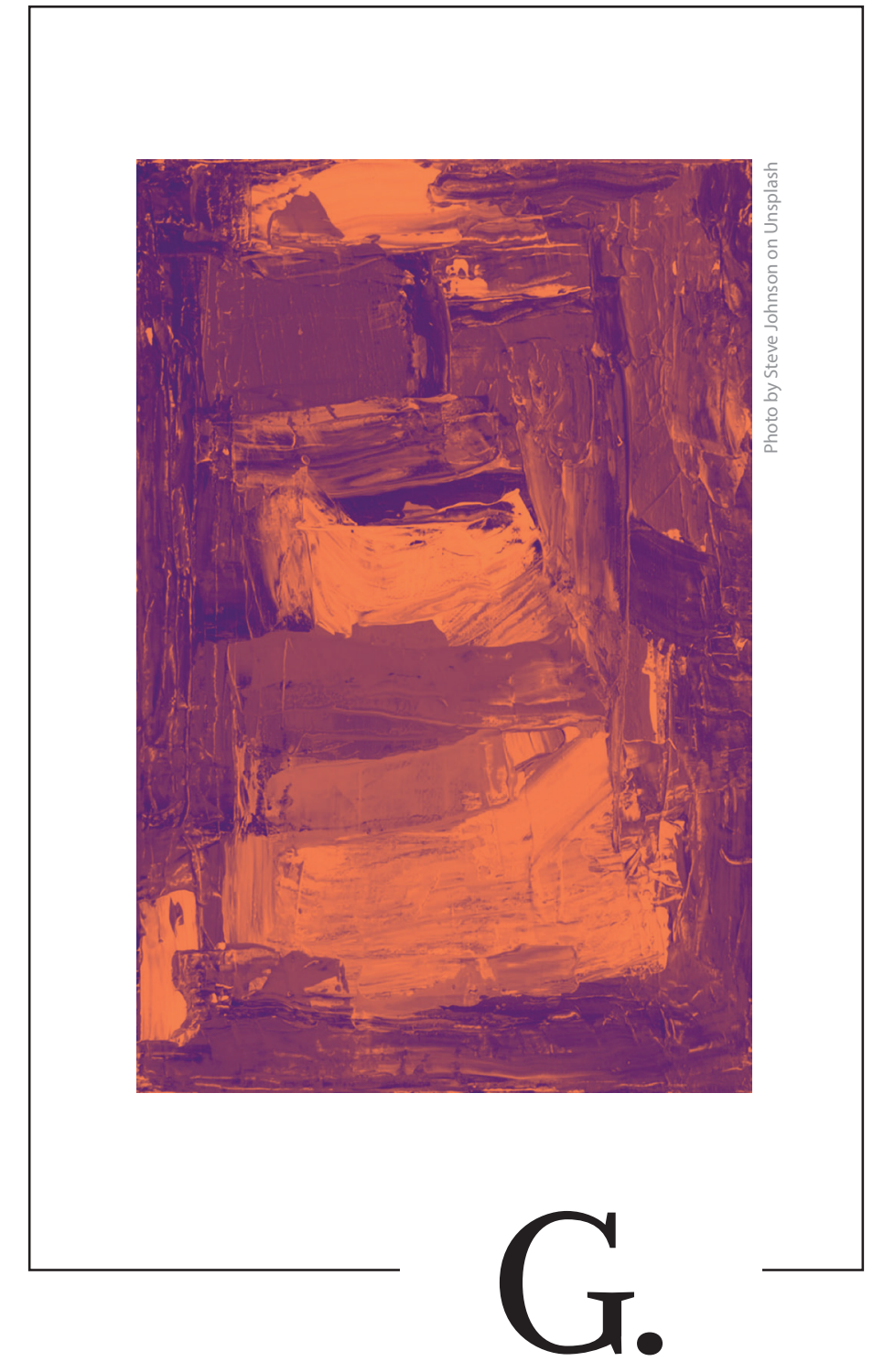

GALERÍA 


\title{
ENRIQUE POLANCO, LOS COLORES DEL INCENDIO
}

\author{
JORGE ESLAVA
}

$\mathbf{U}$

na tarde a inicios de junio del 2020. Cada uno en casa, como corresponde. Su fama de corrosivo y febril hizo que temiera - por un momento - la realización de esta entrevista a causa de los problemas tecnológicos con internet. Luego de largos minutos lidiando con la plataforma, conseguimos conciliar y encontrarnos en la sala virtual, con micro y cámara activados, riendo sobre cuál de los dos era más torpe maniobrando en esta dimensión desconocida. “¿Seguro que me ves?", me preguntaba incrédulo. "Claro, estás con una camisa clara y detrás de ti hay un sable samurái". "Una catana, sí, sí", reaccionó. "Llevas una cadena con un jade circular en el pecho", insistí. "Perfecto", sonrió. "Entonces podemos comenzar".

Afirmaste en una entrevista que, encerrado en tu taller de Barranco, como solías trabajar, "el mundo se puede venir abajo y yo ni me entero".

Correcto, eso lo dije en una entrevista.

Sin embargo, no ha ocurrido así. Vivimos algo parecido al fin del mundo y tú estás sufriendo esta pesadilla... Eso nos demostraría que la realidad una vez más se impone a la ficción.

Mira, esta especie del fin del mundo no me agarra en mi taller. Me agarra en mi casa. Yo tuve tiempo de ir a Barranco y pude sacar unas cosas mínimas para trabajar. Entonces, digamos que me sorprende fuera de sitio. Ahora ya me he hecho un horario de trabajo, con las pequeñas cosas que pude sacar del taller. No me ha faltado trabajo en estos tres meses.

¿Estás trabajando en algún proyecto o no tienes cabeza ni ánimo?

Sí, estoy pintando algunos cuadros de la cuarentena. Son temas diversos. Hay un paisaje urbano solitario, que para mí es un tema recurrente. Probablemente en estos cuadros lo ideal sería que aparezcan luego algunos personajes que hagan imposible no visualizar que fueron hechos en plena pandemia. Pero para eso necesito tener las imágenes completas. Lo que estoy haciendo es la escenografía; de repente, en algún momento, ingresan escenas o quizás quedan así como están. 


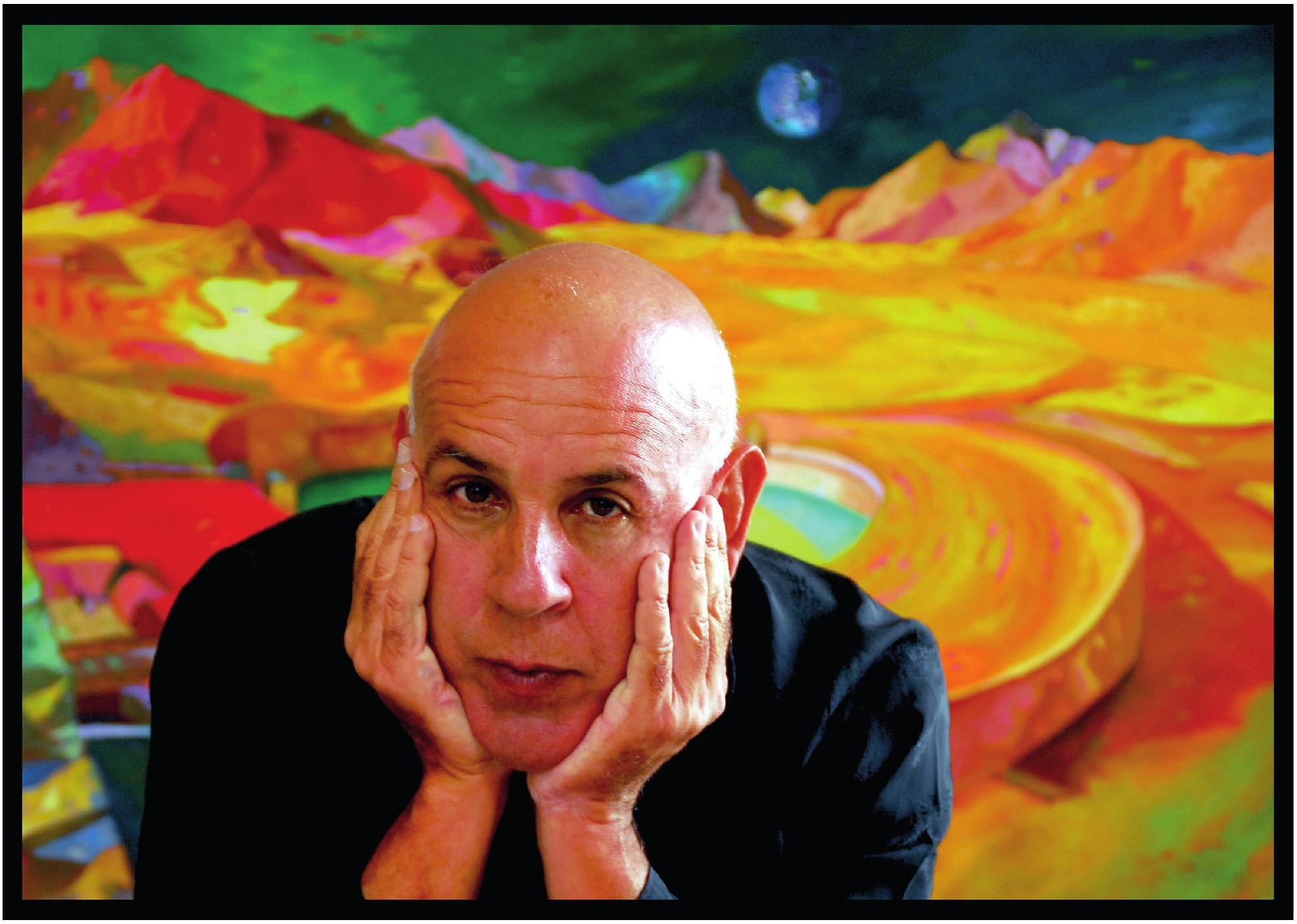

Fotografía: Herman Schwarz*

Sé que estás bien informado, al tanto de las noticias. ¿Es posible, entonces, que algunos personajes o algunas situaciones se filtren en esos escenarios que estás creando?

No podría decirte ni sí ni no. Lo que entraría sería la representación del ser humano en una pandemia, que podría ser representado por alguien con una mascarilla. O la imagen de la muerte podría aparecer mucho, disfrazada de esa cosa redonda y espantosa con la que sale la covid-19.

* Todas las fotografías de esta sección pertenecen a Herman Schwarz, con excepción de Retrato de Martín Adán y De la serie El Tarot: El ahorcado, que son de María Gracia Echevarría y Hairo Dale B., respectivamente. 
O una población protegida con escalafrandas...

Como una representación del virus.

¿Eres selectivo con lo que lees? Porque ahora la información cotidiana contamina, lesiona el ánimo.

En realidad, lo ideal sería no ver las noticias.

¿No sería irresponsable? ¿Tú podrías estar en ayunas de noticias?

Ni hablar, yo soy un ser político. Desde joven, siempre he visto los periódicos, ahora no estoy viendo periódicos porque no los estoy comprando. Pero, bueno, para eso está el Facebook, que es donde nace la confusión, porque aguanta todo.

¿Has visto las escalofriantes escenas de los recolectores de cadáveres? $\mathrm{He}$ leído noticias y sobre todo una crónica, publicada por Ideele, de trabajadores que recogen cadáveres de las casas e incluso de la calle. Parece que es el nuevo oficio de los venezolanos.

¿Sí? No sabía que había recogedores de cadáveres y que los venezolanos están haciendo esa chamba. ¿Quién ha escrito esa crónica? ¿La tienes? Mándamela, por favor.

Sí, claro, te la mando... ¿Crees que las actuales circunstancias van a modificar tu visión? Porque has afirmado que tu pintura no se ha transformado, sino evolucionado. Yo te imagino pintando el mismo cuadro, fundamentalmente un cuadro enorme de Lima, siempre vital y exaltado. Pero ahora no sé, es como si hubieras entrado a una zona de oscuridad y muerte.

Sí, pero considera que en esa zona oscura podrían aparecer las escenas que te digo. Porque yo noto que mi pintura se ha vuelto más violenta en lo cromático. Sin necesidad de escenas ni de personajes, hay una carga visual cromática muy fuerte, muy enérgica, que hace unos meses no existía.

¿Es como volver a tus orígenes de los ochenta, cuando tú mismo te calificabas como un expresionista rabioso? Porque luego tu experiencia en China domesticó un poco ese grito.

En realidad, China no llegó nunca a domesticar ese grito. Lo que hizo fue enseñarme. Conversando allá con compañeros latinoamericanos que tenían más experiencia, pude aprender la teoría del silencio, que es uno de los pilares en los cuales descansa la pintura china.

El silencio en la poesía también.

La poesía y también en la caligrafía. Cuando yo decía eso de que había dejado de ser un poco rabioso, me refería a que mi color, el espíritu del cuadro, había dejado de ladrar un poco. Era más silencioso, no tan evidente. 
Entiendo la influencia que has recibido de algunos expresionistas peruanos como Sérvulo Gutiérrez, Julia Codesido y David Herskovitz. Lo que me sorprende es la mención que haces de pintores de la Colonia como Diego Quispe Tito o Gil de Castro.

Siempre he dicho que soy un amante de la pintura colonial que se hizo en el Perú. Para ser más específico, de la pintura cusqueña. ¿Qué tiene la pintura cusqueña de diferente de la que se hizo en La Paz, en Quito o en Bogotá? Que al pintor indígena peruano le entregaron imágenes de grabados flamencos y él supo borrar la flora y fauna europea e introducir la flora y fauna peruana.

Era una manifestación de rebeldía, de transgresión.

Eso es quizá lo más importante. En diferentes partes de un cuadro ves pájaros de la sierra o plantas andinas. Es una característica importante de la pintura cusqueña. Y si me nombras a Diego Quispe Tito, ¡olvídate!, es el máximo exponente del arte colonial. Gil de Castro es más republicano y también me encanta, no hay más que ver el cuadro de Olaya.

Extraordinario. Y es el único cuadro de un personaje popular que pintó; además, Olaya era su contemporáneo. Por otro lado, me sorprende que no hayas mencionado a Guamán Poma de Ayala, que es el gran insurgente del mundo colonial. Claro, era dibujante y no pintor. Pero ahí está su dibujo abigarrado, sus personajes distorsionados y su carga ideológica que yo advierto en tu pintura.

Desde luego, Jorge, Poma es súper importante. El año 2007, después de mucho tiempo, expuse en una galería comercial, Yvonne Sanguineti, una muestra que se llamaba Camina el autor. Homenaje a Guamán Poma. Lo que hago es traer a Guamán Poma a la cotidianidad limeña. Lo pongo en diferentes circunstancias. Titulé la muestra Camina el autor, porque utilizo un dibujo de él caminando con su familia: su perro, su caballo y su hijo. Y también soy yo caminando por diversos lugares; es decir, tenía esa doble interpretación.

He visto algunas de esas pinturas... pero me refería a una filiación.

No, sí hay una identificación. Guamán Poma fue el primer cronista indígena de la Colonia y me siento representado en sus andanzas. Cuando investigué sobre él y me enteré de toda su experiencia, además de que murió en Lima, algo que jamás imaginé, sentí que Poma caminaba en todos mis cuadros, como yo.

Tú has sido siempre un andariego conspicuo... ¿y has ido también quejándote de esta Lima desigual, maltrecha?

Sí, pero también asombrándome. Además, Poma venía ya prestándome algunas de sus imágenes y hasta de sus colores andinos... 
Pero él también era furibundo en su crítica, por eso escribe esa carta monumental al rey. ¿No crees que tu pintura comparte ese espíritu?

Mira... me has hecho pensar. Puede ser que mis pinturas tengan algo de suspicacia o sean cachosas, por ejemplo, poner una tapada en el Mirador de Ingunza, que es el último monumento de la Colonia que queda. O pintar el sicariato que hemos visto en Lima, un tipo en moto y con una pistola. También hay un terreno abandonado donde están juntos la patria y la muerte, o la casona El Buque, que es una zona bien pastrula en medio de todo un espectáculo tradicional, o Dante al lado de una mototaxi en el cerro San Cosme, como si estuviera en el infierno, ¿no? Sí, tienes razón, es crítica social lo que hago.

Con el homenaje a Poma volviste a exponer en una galería. Porque habías abandonado las galerías o te habían abandonado hacia el 2002 o 2003.

Es cierto lo que dices. Mi última muestra había sido donde Cecilia González, en El Olivar. Cuando ella cerró, yo me aparté de las galerías hasta el año 2017 en que hice esta muestra. La organizó el Museo de Etnología de Holanda al cumplirse los 400 años de la aparición de la Nueva corónica y buen gobierno; el entonces embajador peruano, el escritor Carlos Herrera, me solicitó dos cuadros. Mi pintura cierra esa muestra impresionante sobre la obra de Guamán Poma.

Era agregar un eslabón más a la cadena de tus tributos. Porque también recuerdo unos hermosos homenajes a Martín Adán y La casa de cartón, y a Martín Chambi y su obra fotográfica. ¿Qué otros autores peruanos te gustaría abordar?

Me gustaría mucho abordar a Vallejo, a Mariátegui, a Toño Cisneros.

¿A Toño no lo homenajeaste en una oportunidad?

Exacto, era una muestra que tenía planificada en la Municipalidad de Miraflores. Toñito nos abandonó unos meses antes y la muestra salió como un homenaje a Antonio Cisneros.

Con él formabas un grupo peculiar. ¿Me cuentas un poco sobre tu relación con él y el llamado Club de Toby?

Creo que he sido el último en ingresar al club, porque ya estaban Antonio Cisneros, Lorenzo Osores, Talo Núñez, Juan Acevedo, Carlín (Carlos Tovar). Como ves, solo nos reunimos hombres y no era un jolgorio, tomábamos simplemente café y conversábamos sobre temas variados.

Pero bien afilado el humor...

Bueno, todos eran muy ocurrentes, pero tú sabes cómo es Lorenzo, sobre todo. 


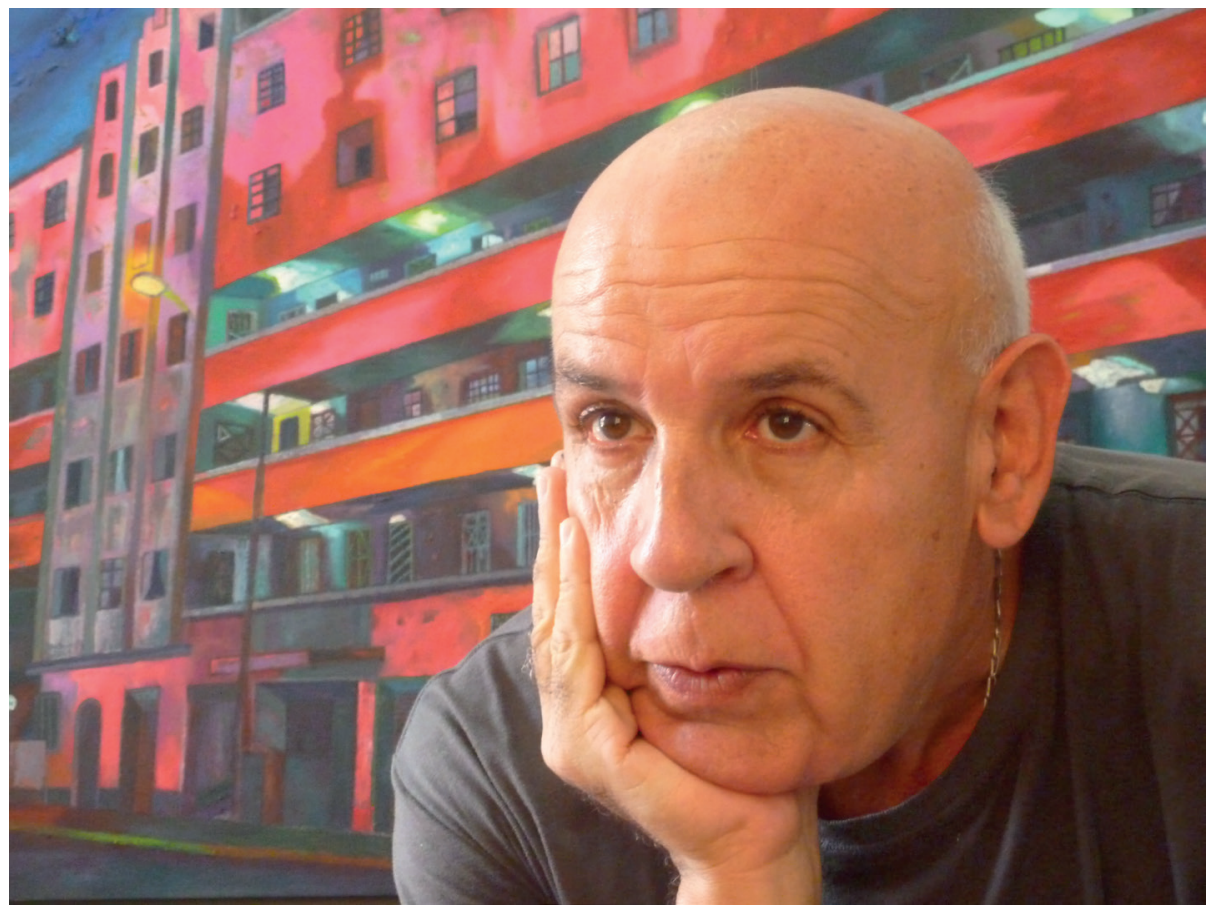

¿Y no merodeaba ninguna Lulú?

No, a las Lulús las invitamos solo en Año Nuevo. Al almuerzo que hacíamos. Pero todo eso desapareció con la partida de Toño. Él era, no sé quién lo dijo, "el poeta que amaba a la gente". Él nos encontraba, nos juntaba y toda esa fiesta también desapareció.

Toño tenía muchos amigos y varios grupos. Yo pertenecía, ocasionalmente, al grupo de los ciclistas. Con Willy Niño de Guzmán y Fernando Ampuero, alguna vez Julio Ramón Ribeyro.

Ah, mira, tú también estabas en el grupo de los ciclistas. Ustedes recalaban en ese bar español que había medio escondido en Pedro de Osma.

La Tasca Vasca, claro. ¡Preparaban unos garbanzos y tenían un excelente vino español! Y siempre era Toño el más entusiasta; además, era un buen ciclista. ¿Quién no tiene anécdotas con él! "Primero el esfuerzo y después el placer", decía para obligarnos a ir hasta el extremo de La Herradura. Sé que lo viste la víspera de su muerte.

Sí, lo vi con Lorenzo Osores a mediodía y falleció en la madrugada siguiente. Estuvimos largo rato conversando, estaba totalmente entero. Grandote, inmenso como era y lúcido, de buen humor, enfrentando de una manera maravillosa a la parca. 
Con la mayor dignidad.

Exactamente.

Otra relación por la que tengo curiosidad es tu vínculo, creo que entre amigable y díscolo, con la gente de Kloaka.

A la gente de Kloaka la conocí el año 82, a través de Roger Santiváñez. Ellos bajaban del Centro de Lima al Juanito. En esa época, Barranco era un pueblito donde todos nos conocíamos, sumamente tranquilo, no era ni la sombra de lo que se convirtió después. Era un bar-bodega adonde iban siete viejitos. No es por estar hablando cosas, pero cuando me fui a China, la despedida la hicimos ahí en el Juanito. Con músicos, con Del Pueblo y del Barrio y, sin querer, Barranco se transformó.

Pasamos de esa pregunta, entonces...

No, sí quiero terminar de contestarla. Kloaka fue un movimiento muy joven. Yo conocí a todos los poetas fundadores, porque ellos hacían lo mismo que yo hacía en pintura. Una expresión social muy política, muy crítica. Entonces nos conocimos y hubo empatía, acabamos juntos y ellos me integraron al movimiento, pero mi estadía duró muy poco. Terminamos un poco distanciados, por equis motivos y después yo partí de viaje.

Si me permites incidir en la experiencia de Kloaka, no específicamente en el grupo, sino en lo valioso que era participar en un colectivo con pintores, músicos, poetas... gente cercana a la rebeldía social, a la protesta...

Muy cercana. Esas movidas eran importantes. No me atrevería a afirmar si hoy existe o no lo que existía en los ochenta, que extrañamos nosotros y lo vemos con nostalgia. Creo que algo hay y es la misma gente del grupo fundacional de la música de aquella época que fue Del Pueblo y del Barrio. Piero Bustos y toda esa gente organizaron Kuntur Rock y esas cosas. Hay una movida subterránea, que no conozco mucho porque no la frecuento, pero me parece que algo ha quedado.

Creo que los músicos subterráneos tuvieron mayor repercusión que los poetas y narradores de aquella época. Era el canal de estampida política. Uno revisa esas canciones y eran abiertamente transgresoras.

Bueno, Del Pueblo y del Barrio fue el inicio de toda esa onda. Después vinieron Los Mojarras y otros más roqueros...

Tú eras un muchacho miraflorino... Habías terminado el colegio, no habías postulado a la universidad. Tal vez te "correspondía" estudiar en una universidad privada, pero te demoras y postulas a la Escuela de Bellas Artes. ¿Qué pasó en la familia, algún traspié económico? 
¿Por qué no fui a la Católica? Bueno, mi padre no hubiera podido pagar ni siquiera diez días de la Católica. Por eso fui a Bellas Artes. Yo recuerdo que salí del colegio y me pasé como dos años sin hacer nada. Mi viejo por ahí me consiguió una chamba en el Ministerio de Energía y Minas, y acabé de dibujante en el servicio de geología y minería del Perú. Entré sin saber nada, como se hacían los dibujantes tecnológicos en aquella época. Poco a poco fui aprendiendo, todo era a mano, ya después la cosa empezó a tecnificarse. Un día temprano, sentado en mi tablero, revisando el periódico, leo un aviso que dice algo así: "Comunicado de la Escuela Nacional Autónoma de Bellas Artes. Se comunica a los postulantes del año académico 1974 que el día lunes vence el plazo para presentar toda la documentación y poder rendir examen para la prueba de admisión". Yo leí y entonces me dije: “Qué es esto? ¿La Escuela de Bellas Artes?”. Averigüé algo y saqué todos los documentos que me pedían, me presenté e ingresé. Entonces, ipucha madre!, decirle a mi viejo: “Oye, papá, no voy a trabajar más y voy a estudiar pintura”.

Un escándalo, ¿tú eres hijo único?

No, somos tres hermanos. Me acuerdo de que antes de eso me fui a Tumbes, a Puerto Pizarro, a meditar bien la decisión. Yo tenía 20 años, era un muchachito con un buen trabajo y ganaba bien. Les daba propina a mis hermanos. Pero, a partir de ese aviso premonitorio, se me metió el bicho a la cabeza. Me dije: "Quiero ser artista". Cuando volví del norte hablé con mi padre: "Papá, mira, yo...", y me contestó: "Ya, perfecto, hazlo si es tu deseo hacerlo, pero tú sabes que no voy a poder ayudarte mucho, pero, bueno, en lo que pueda". Él me dio el impulso moral; entonces, me hice alumno libre el primer año, no dejé del todo el trabajo. Iba a la escuela por las tardes con saco y corbata. Al año siguiente dije: "No" y renuncié a mi trabajo, me quedé como alumno regular, terminé los cinco años y me gradué de Bellas Artes.

¿Fue un autodescubrimiento o hubo alguien en tu casa o en el colegio que te dijera: "Oye, chico, tienes talento, por qué no te dedicas a la pintura"?

Sí, mira, yo dibujaba bastante bien. En el colegio tuve la suerte de contar con un gran profesor de arte. Un escultor, Manuel Gómez, egresado en los años sesenta o cincuenta de la Escuela de Bellas Artes. Él incentivó mucho mi vocación hacia la pintura, me hablaba de la escuela. Siempre me sacaba muy buenas notas en pintura, pero cuando salí del colegio ya nunca más volví a pensar en la Escuela de Bellas Artes, hasta aquel día en que leí el aviso.

Pero tenías las palabras del profesor guardadas en algún rincón. Fue en el colegio Olaya, ¿no?

Yo estudié hasta cuarto de primaria en el Champagnat, de ahí en el José Olaya. Tengo una anécdota de muy niño, cuando paraba mucho en casa de una tía que vivía en Shell, casi con Larco. Iba a escuchar música porque ella tenía una radiola y en esa época no todos teníamos radiola. Al costado estaba la librería 
La Familia. Entonces yo escuchaba música y después me pasaba a la librería. Me había hecho amigo del que atendía, como iba todos los días. Él me permitía limpiar los libros con un plumero y un día junté dinero y me compré un libro de Goya. Tendría yo 12 años, 13 años. Ese fue mi primer acercamiento a la pintura: un libro de Goya comprado con mi propina.

Linda historia. ¿Y qué música escuchabas en casa de tu tía? ¿Popular o clásica?

Yo escuchaba mucho a los Bee Gees. Era la música del momento. Recuerdo mucho una canción que la repetía a cada rato, debo haber rayado el disco de mi tía: Massachusetts, por los Bee Gees. Eso que se acaba y la vuelves a poner durante todo el día... (risas).

Volvamos a mediados de los setenta, cuando eras un estudiante a tiempo completo. Si no trabajabas, ¿de dónde sacabas el billete para el trago y el burdel?

Salían de lo que mi padre me daba para el pasaje.

Perdona la grosería, Enrique, pero pertenecemos a una generación que respetaba sus rituales.

Desde luego, en la época del colegio y en los viajes que hacíamos. Una vez hicimos un viaje a Huancayo y toda la promoción terminó en el burdel. Ese fue el debut de este pintor... (risas). Como te digo, mi padre me ayudaba con mis pasajes y para almorzar. Almorzábamos con un sol en un famoso lugar que estaba cerca de la escuela, en la plazuela de la Buena Muerte. Era una pescadería famosa y ahí te comías una bacinica de aguadito de pescado y ya estabas pal' otro lado. Con un sol.

En San Marcos el menú costaba 50 céntimos y al comedor lo llamábamos "La muerte lenta".

Claro, la muerte lenta en ambos casos (risas). Y el trago salía de un estudiante amigo nuestro, arequipeño, Percy Herrera, que era el más adinerado de ese grupo de mataperros misios. Como él tenía su pensión todos los meses, se la gastaba chupándosela con nosotros.

Es en esa época cuando nace tu mítica amistad con Humareda.

Exactamente.

Que si bien no fue una amistad decisiva en tu vida, sin duda fue un horno que terminó por cocer bien al pintor.

Tú lo has dicho. No ha sido decisiva, pero Víctor Humareda fue la primera persona que inyectó el color y el amor a la pintura en mis venas. Eso ya es bastante. A Víctor yo lo conocí un día en la escuela de una manera que ya he contado varias veces. Y de ahí lo visité muchísimo. Dos veces a la semana. Nos 
hicimos amigos, él me buscaba en la escuela. No sé, este personaje maravilloso de repente vio algo en mí. Talento, no sé. Entonces nació una amistad entre mí, con 21 años, y Humareda, que tenía sesenta y tantos.

A Humareda se le trataba de atribuir un vicio, no sé si por su aspecto extravagante o por sus enemigos. Se decía que era borracho.

Víctor nunca tomó trago, el único vicio de Humareda era la belleza, la pintura y los burdeles. Le gustaba la manzanilla y amaba la belleza por sobre todas las cosas. Adoraba a Marilyn Monroe.

¿Cierto que ibas con él al burdel?

Claro, íbamos a La Nené y él realmente se ocupaba, se ocupaba...

Humareda muere cuando tú estás en China y la noticia te la da Herman Schwarz. ¿Cómo la recibiste?

Sí, Herman me escribió. Lógicamente en esa época nadie llamaba por teléfono a China, porque era carísimo, te podía costar una fortuna. Fue duro, me enteré por una carta, igual que cuando murió mi padre. Ubicarme en China era muy difícil, lo hicieron después de diez días de muerto mi padre.

Tú habías continuado la ruta apasionada de tu pintura. Supongo que la fiebre inyectada por Humareda estalla con más potencia en China, porque este es un país muy colorido.

Es un país totalmente colorido, diría casi kitsch, al menos en esa época. A mí me tocó vivir un momento muy interesante, que es verdaderamente casi el final del maoísmo. Ya Deng Xiaoping tenía diez años en el poder, ya había pasado el famoso juicio a la viuda de Mao. La Revolución Cultural había ocurrido hacía diez años. Cuando llego a China, los ciudadanos chinos aún se vestían de tres colores. Todavía estaba prohibido para los extranjeros visitar algunos lugares. Así fue el primer año que yo estuve, después ya abrieron China completamente. Y más que nada estaban cerradas las regiones autónomas de China, que congregan a cincuenta y tres nacionalidades.

Y viajaste mucho...

Sí, gracias a eso pude hacer la Ruta de la Seda, que fue un viaje maravilloso. Seis días de viaje desde Pekín para llegar a un pueblo que es casi ya el límite con lo que ahora es Kazajistán. Urumushi, que fue parte de la Ruta de la Seda, por ahí pasó Marco Polo. Yo he paseado en taxi-burro, sentado en una alfombra sobre una plataforma jalada por un burro. Por ciudades que son ya cascos, solamente de adobe. Unas ciudades maravillosas que fueron totalmente luminosas en la época de la Ruta de la Seda. En China yo he hecho viajes verdaderamente alucinantes; he viajado seis días para ver un Buda enclavado en la roca de quince 
metros, he ido al sur, a la selva, he visto elefantes. En China conocí todo, conocí las estaciones del año, la lluvia y el sol sofocante. Un día me despierto y miro por la ventana y estaba todo blanco. Yo nunca había visto nieve.

Tampoco conocías el horóscopo chino, ¿no? Sé que perteneces al año de la serpiente.

Claro, como tú también. Si eres del 53, eres serpiente.

Soy de diciembre del 53 y tú de noviembre. ¿Y cuáles son sus defectos?

Ninguno, pues.

Ah, ya, con razón, ahora sí suscribo (risas).

Yo en la astrología china soy serpiente y en el zodiaco, escorpión, totalmente viperino. Por eso una vez me dijo Martha Hildebrandt: "Enrique, los escorpiones sostienen al mundo". Digamos que esa es mi radiografía mística.

¿Fuiste a China como estudiante o con un compromiso de trabajo?

Exclusivamente como estudiante. Después, los estudiantes terminábamos siendo muy amigos de los expertos, porque en esa época iban muchos expertos, entre los cuales había muchísimos peruanos, que eran los que iban a ayudar a los chinos en corrección de estilo.

\section{Como Lorenzo Osores y Mito Tumi.}

A Lorenzo lo conocí en esa época. Mito Tumi llegó un año después, pero anteriormente habían estado Mirko Lauer y Leonidas Ceballos. Creo que el que abrió la ruta a China fue Antonio Fernández Arce, un periodista.

Me dijiste al comienzo de esta conversación que ahora pintas en casa. ¿Qué material lograste sacar del taller para atrincherarte en casa? También me dijiste que tu mujer y tú se han impuesto horarios... Me gustaría saber tus horarios, tus manías, todo ese escenario. Por ejemplo, sé que escuchas música clásica cuando trabajas.

Hace muchos años que en Barranco yo trabajo escuchando música clásica, es una música que no molesta, siempre está acompañándote. Es una música exquisita, maravillosa. Pero acá estamos escuchando una estación de radio por internet, accujazz.com, ahí escuchamos jazz y música de diferentes partes del mundo. ¿Qué logré sacar de Barranco? Algunos colores y un par de telas. Y acá, en el lugar donde vivimos, está el taller de mi esposa, entonces, lo estamos usando los dos. 
Sin conflictos, imagino.

Sin conflictos, pero lo ideal es trabajar solo. Yo estoy acostumbrado a trabajar solo, siempre he trabajado solo.

¿Y es porque tienes tus manías, tus horarios, tu manera de trabajar?

Generalmente nosotros despertamos muy temprano. La cuarentena ha variado un poco nuestros horarios. Antes de toda esta pesadilla, yo salía a caminar solo, muy temprano, por el malecón. A las cuatro y cuarto ya estaba en la calle, pero ahora nos hemos vuelto un poco más flojos y nos despertamos a las cinco y media. ¿Qué hago ahora? Hago caminatas dentro de la casa, me doy quinientas vueltas a la sala como un león enjaulado. Una hora todos los días y de ahí subimos al tercer piso, al taller, y cada uno se pone a trabajar. Esa es mi rutina hoy en día.

Cuando despertemos de esta pesadilla, que espero sea pronto, no veo con optimismo los tiempos que vienen. No sé si Lima va a ser más amable, pero sí temo una ola delincuencial bárbara. ¿Qué piensas?

La verdad, soy bastante escéptico de que vayan a ocurrir muchos cambios. No creo que este capitalismo salvaje que le ha hecho tanto daño al planeta vaya a desaparecer de la noche a la mañana. No soy muy optimista; es más, pienso que va a aparecer más desesperado que nunca a recuperar el tiempo perdido.

Por salud prefiero no proyectarme, ya estoy bastante afectado con la información cotidiana y el esfuerzo de la sobrevivencia diaria.

También estoy en las mismas. Te juro que yo en las mañanas me despierto con un desánimo a veces, con cólera de todo lo que está pasando. Te mentiría si te digo que no, pero es así. Y la incertidumbre de leer tanta información que, en muchos casos, es contradictoria. Yo, por ejemplo, no sé en qué etapa de la pandemia estamos en el Perú. Porque parece que la cosa se está poniendo más fea. 